\title{
Equilibrative Nucleoside Transporter 1
}

National Cancer Institute

\section{Source}

National Cancer Institute. Equilibrative Nucleoside Transporter 1. NCI Thesaurus. Code C105063.

Equilibrative nucleoside transporter 1 (456 aa, $\sim 50 \mathrm{kDa}$ ) is encoded by the human SLC29A1 gene. This protein is involved in mediating nucleoside influx and efflux. 